\title{
INDUSTRIAL RELATIONS PERFORMANCE, ECONOMIC PERFORMANCE, AND QWL PROGRAMS: AN INTERPLANT ANALYSIS
}

\author{
HARRY C. KATZ, THOMAS A. KOCHAN, and \\ KENNETH R. GOBEILLE*
}

\begin{abstract}
This study analyzes the relationship among plant-level measures of industrial relations performance, economic performance, and quality-ofworking-life programs. The analysis employs pooled time-series and crosssection data from 18 plants within a division of General Motors for the years 1970-79. The empirical results show strong associations between industrial relations and economic performance measures and limited support for the hypothesis that quality-of-working-life efforts improve both kinds of performance.
\end{abstract}

$I_{\mathrm{s}}^{\mathrm{N}}$ N RECENT years, industrial relations scholars have lamented the field's preoccupation with comparisons of union and nonunion settings and have stressed the need to examine the diversity of experience in different unionized settings. ${ }^{1}$ At the same time, scholars have also recommended that more bargaining research be based on micro-level data. Both of these recommen-

\footnotetext{
*Harry Katz and Thomas Kochan are, respectively, Associate Professor and Professor of Industrial Rela. tions at the Sloan School of Management, Massachusetts Institute of Technology, and Kenneth Gobeille is a Supervisor of Salaried Personnel of the General Motors Corporation. The authors wish to thank Anil Verma for his excellent assistance in data analysis. They also thank the staff of the General Motors Corporation for their assistance in collecting these data and for their comments on the paper. Partial support for this research was provided by the Sloan Foundation.
}

'This point is stressed in Thomas A. Kochan, Labor Management Relations Research Priorities for the 1980s (Washington, D.C.: U.S. Department of Labor, 1980), pp. 20-22. See also John T. Dunlop, "Policy Decisions and Research in Economics and Industrial dations have been made in recognition of the need to assess the performance of industrial relations systems at the workplace and the results of change strategies designed to improve that performance. ${ }^{2}$

While these ideas have been evolving within the research community, a number of companies and unions have been experimenting with new strategies for improving the performance of their bargaining relationships at the plant level through what

Relations," Industrial and Labor Relations Review, Vol. 30, No. 3 (April 1977), pp. 275-82. For a call for similar research from a practitioner's viewpoint, see Audrey Freedman, "A User's Agenda for Labor Management Relations Research," in Barbara D. Dennis, ed., Proceedings of the Thirty-Third Annual Meeting of the Industrial Relations Research Association (Madison, Wis.: Industrial Relations Research Association, 1981), pp. 22 - 25.

${ }^{2}$ For a more complete discussion of these arguments and of the concept of "performance" or "effectiveness" in collective bargaining, see Thomas A. Kochan, Collective Bargaining and Industrial Relations: From Theory to Policy and Practice (Homewood, Ill.: Irwin, 
generally have been labeled "quality of working life" (QWL) programs. ${ }^{3}$ The common thread running through these efforts is their attempt to establish practical relationships outside such traditional unionmanagement activities as arms-length negotiations, formal and informal grievance handling, and union-management committees. Instead, QWL programs represent an attempt to establish direct channels of communication between workers and their supervisors and involve workers in shop-floor decision making. It is through this process that the participants hope to improve both organizational effectiveness and the psychological rewards workers obtain from their jobs. ${ }^{4}$

These QWL programs hold the potential for significantly altering the conduct of labor relations in the United States. Indeed, the popular press and media have given a tremendous amount of attention to these efforts. They are often seen as part of the solution to sluggish productivity growth, as a way of easing the traditional

1980), pp. 25 - 32; Milton Derber, W.E. Chalmers, and Milton Edelman, "Assessing Union Management Relations," Quarterly Review of Economics and Business, Vol. 1, No. 4 (November 1961), pp. $27-40$; and Jeanne M. Brett, "Behavioral Research on Unions and Union Management Systems," in Barry Staw and L.L. Cummings, eds., Research in Organizational Behavior, Vol. 2 (Greenwich, Conn.: JAI Press, 1980), pp. $188-93$.

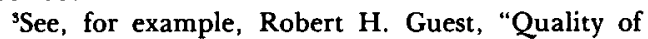
Work Life - Learning from Tarrytown," Harvard Busi. ness Review, Vol. 57, No. 4 (July-August 1979), pp. 76 87; Stephen H. Fuller, "How Quality of Worklife Projects Work for General Motors" Monthly Labor Review, Vol. 103, No. 7 (July 1980), pp. 37-38; and Irving Bluestone, "How Quality of Worklife Projects Work for the United Auto Workers," Monthly Labor Review, Vol. 103, No. 7 (July 1980), pp. 39-40.

"For a summary of the theoretical assumptions underlying $Q W L$ and other forms of worker participation, as well as a comprehensive review of the empirical literature on these subjects, see Jeanne Brett and Tove Hammer, "Organizational Behavior and Industrial Relations," in Thomas A. Kochan, Daniel J.B. Mitchell, and Lee Dyer, eds., Industrial Relations Research in the 1970s: Review and Appraisal (Madison, Wis. : Industrial Relations Research Association, 1982), pp. 221-42. For the most comprehensive empirical evaluation of a QWL effort see Paul S. Goodman, Assessing Organizational Change: The Rushton Quality of Work Experiment (New York: WileyInterscience, 1979). See especially pp.7-8 for a discussion of the joint objectives of QWL efforts. adversary relationships between labor and management, and as signifying a "New Industrial Relations."5 As yet, however, we have primarily anecdotes, speeches, and case studies extolling the virtues of these strategies, rather than hard empirical evidence on their lasting effects. Analysis of the impact of these QWL programs requires that researchers control for the effects of other possible influences - in fact, that researchers conduct the very sort of microanalysis that industrial relations researchers have been recommending. ${ }^{6}$

No well-developed theory or set of propositions exists, however, that relates variations in plant-level industrial relations outcomes obtained under collective bargaining to productivity or any other measures of organizational effectiveness. We do have hypotheses regarding the shock effects of collective bargaining on management policy and behavior, ${ }^{7}$ the voice effects of unions, ${ }^{8}$ and the human resource and technological adjustments employers make to changes in bargaining agreements. ${ }^{9}$ These hypotheses, however, generally ad-

\footnotetext{
5"The New Industrial Relations," Business Week, May 11, 1981, pp. 85-98.

${ }^{6} \mathrm{~A}$ similar argument for more systematic evaluation and less reliance on qualitative case studies is made by Brett and Hammer, "Organizational Behavior," p. 23, on the basis of their review of both U.S. and European styles of worker participation. They conclude, "We have learned more about the effects of ... participation from the few carefully designed studies than from the numerous case reports available. It is high time participation researchers move beyond evaluation by storytelling."

${ }^{7}$ The shock-effect hypothesis is usually traced to the work of Sumner H. Slichter, Union Policies and Industrial Management (Washington, D.C.: The Brookings Institution, 1941), p. 579. For a later elaboration of the hypothesis, see Sumner H. Slichter, James J. Healy, and E. Robert Livernash, The Impact of Collective Bargaining on Management (Washington, D.C.: The Brookings Institution, 1960), pp. $9-26$.

${ }^{8}$ For a discussion of the voice effect as well as other ways in which unions affect workers and employers, see Richard B. Freeman and James L. Medoff, "The Impact of Collective Bargaining: Illusion or Reality?" in Jack Stieber, Robert B. McKersie, and D. Quinn Mills, eds., U.S. Industrial Relations 1950-1980: A Critical Assessment (Madison, Wis.: Industrial Relations Research Association, 1981), pp.47-98.

${ }^{9}$ Management adjustment processes are discussed in Kochan, Collective Bargaining and Industrial Relations, pp. $331-35$.
} 
dress the average effect of unions and collective bargaining rather than the effect of variations in features of the industrial relations system. None of these hypotheses, furthermore, helps explain how QWL efforts can be expected to affect the industrial relations system or organizational effectiveness. Thus, for both theoretical and applied reasons, industrial relations researchers need to address the rationale underlying QWL strategies and their results.

This paper serves as an exploratory effort to address these questions by examining the relationship among multiple indicators of industrial relations performance, the economic dimensions of organizational effectiveness, and QWL efforts at the plant level. It is exploratory in the sense that it draws on a rich body of plant-level data seldom available to researchers to test the strengths of the associations between measures of industrial relations performance and economic performance. Our purpose is to generate propositions rather than to test them formally, since an adequate theoretical structure for relating these concepts has yet to be developed. Nevertheless, the data do allow us to test a number of generally accepted, yet heretofore untested, propositions regarding the interrelationships among different dimensions of industrial relations performance.

Finally, since the data are drawn from the files of 18 General Motors (GM) plants for the years $1970-79$, we can begin to assess the effects of the well-publicized QWL efforts that began in this corporation during these years. We do not present our findings as a formal evaluation of the QWL efforts, since only limited data are available from only a subset of the plants. A comprehensive evaluation would require data on a broader array of process and outcome measures and data from a wider sample of plants. The data do provide an ideal opportunity to examine empirically the diversity of results that can be obtained by the same company and union operating under the same basic technology in different plants and to examine the potential the parties have to alter these results.

\section{The General Model}

Collective bargaining researchers have traditionally focused on the formal procedures of contract negotiation and administration and on the rules that govern employment relationships. Our interest here is in extending this work by relating variations in the effects of negotiation and administrative procedures to variations in plant-level economic performance.

We argue that contract negotiation and administration procedures will interact with and influence the attitudes and behaviors of the workers and mangers who together establish the attitudinal climate of the workplace. ${ }^{10}$ We further expect that variations in the outcomes or performance of industrial relations processes and procedures influence plant-level economic performance through their effects on labor costs, productivity, and product quality. QWL efforts are viewed in this analysis as strategies for involving workers in ways that are designed to change attitudes and behaviors and thereby improve both industrial relations performance and economic performance. ${ }^{11}$ These general conceptual arguments are used to guide the exploratory analyses that follow.

Four interrelated dimensions of plant-

\footnotetext{
${ }^{10}$ For a basic theoretical discussion of the relationship between the attitudinal climate and other aspects of a collective bargaining relationship, see Richard E. Walton and Robert B. McKersie, A Behavioral Theory of Labor Negotiations (New York: McGraw-Hill, 1965), pp. $184-280$.

"Obviously, other, more complicated causal relationships could be proposed for relating the broad concepts of industrial relations performance, economic performance, or organizational effectiveness to QWL intervention efforts. One could argue, for example, that there are feedback or reciprocal relationships between industrial relations and economic performance. While we acknowledge that these more complex relationships may exist, we are suggesting here that the predominant causal direction is from industrial relations to economic performance. This view is consistent both with the conventional literature, cited above, on the effects of collective bargaining and with the efforts of management, union, and neutral practitioners who are attempting to change the workplace through QWL interventions. Thus, for both theoretical and practical reasons, this is the model of central interest to industrial relations professionals and therefore the approach taken in our analysis.
} 
level industrial relations performance are analyzed in this study. These dimensions and their associated measures are: (1) the attitudinal climate of the unionmanagement relationship, measured by an attitude survey; (2) the results of the contract administration process, measured by both grievance and discipline rates; (3) the intensity of contract negotiations, measured by the number of demands introduced in local contract negotiations and the length of time taken to reach local agreements; and (4) individual worker behavior, measured by the rate of absenteeism in the plant. Although these measures are not posed as exhaustive indicators of industrial relations performance at the plant level, they do focus on four of the most important dimensions of the collective bargaining relationship.

In this analysis, these industrial relations performance measures are viewed as systematically interrelated in a complex cycle that is perpetuated over time such that a simple cause-effect relationship may be impossible to discern. Indeed, there may be little practical value in attempting to specify the precise direction of the casual relationships among these performance measures, since over successive rounds of bargaining, conflicts from one aspect of the relationship are likely to carry over to the others and thereby blur the origin of the casual chain. For example, unresolved grievances are likely to turn into contract proposals and thereby produce more hostile attitudinal relationships, perhaps also leading to higher levels of absenteeism. Or the cycle could just as easily begin with a particularly difficult round of negotiations, which later affects the grievance procedure, union-management attitudes, and employee behavior. The critical question, therefore, is whether QWL programs (or some other intervention) can break into this causal chain, produce improvements in one or more of these dimensions, and thereby alter the performance of the others. An ancillary question is whether these QWL efforts either directly or through improvements in industrial relations performance lead to improvements in the quality of workers' jobs and improved economic performance for the firm.

\section{Data and Analysis Plan}

The data for this study were collected from company files on 18 plants in which joint efforts with the United Automobile Workers were under way during the years 1970-79. The plants are all in one GM division in which the technology and product are very similar. Four of the plants, however, did not report data for 1970. The overall data set thus provides a pooled cross-section sample of 176 observations for most of the industrial relations and economic performance measures. Missing data on a small number of variables reduces this sample in some of the analyses. Only four rounds of bargaining occurred during this period $(1970,1973,1976$, and 1979), and some of the plants did not report bargaining data for the 1970 and 1973 rounds. The maximum sample size for data on the negotiaton process is thus 68. It should be noted that this local bargaining was supplemental to national contract negotiations.

GM began administering a QWL attitude survey in its plants in 1976. Although the time of administration in each plant varied and therefore did not correspond precisely to the calendar year from which the other data derive, there were 65 such surveys administered between 1976 and 1979. The survey provides a composite score of responses by managers and supervisors to five questions concerning the degree of trust and cooperation between the union and management in a plant. That score is summarized in a variable we label Climate.

Starting in 1977, each plant reported annually to division headquarters on the QWL efforts under way in the plant. The measure used here of the intensity of the QWL effort is derived from a content analysis of these reports and therefore is only available for the years $1977-79$. The procedures used in this content analysis are described in the appendix. Although some of the plants may have started their QWL programs before 1977, we have no way of measuring this; the intensity measure therefore contains some degree of measurement error.

We measure the economic performance of each plant with two indices computed by 
General Motors. A quality index is derived from a count of the number of faults and "demerits" that appear in inspections of the product; this index is available for 1973 to 1979. An efficiency index for direct labor, available for 1970 through 1979, compares the actual hours of labor input by production workers to standardized hours calculated by GM's industrial engineers. The higher the efficiency index, the higher is efficiency and the lower are costs. The criteria for labor standards employed in this index include consideration of variations in product attributes. Both the quality and direct-labor indices are annual plant averages.

We will treat these data as a pooled crosssectional sample that measures only some of the relevant theoretical determinants of industrial relations performance and economic performance. Of all the environmental and organizational variables that could be measured, only those that could be measured by the data available from company files and reports could be employed here. These data are exceedingly rich, but they do not incorporate all of the potentially important sources of variations in the dependent variables, such as turnover of top plant management or union leadership, internal union and management political characteristics, or differences in the technology and skill mix in the plant.

To the extent that these unmeasured factors are randomly distributed across these plants, they will not bias the coefficients obtained in our analysis; however, to the extent that they are correlated with a measured variable, they will bias the coefficients. ${ }^{12}$ Thus, in some of the analyses, we introduce dummy variables to capture the unique, plant-specific unmeasured variables that may otherwise bias our results - a technique that is equivalent to estimating a fixed-effects model.

The analysis starts with a description of

\footnotetext{
12See, for example, Richard J. Butler and Ronald G. Ehrenberg, "Estimating the Narcotic Effect of Public Sector Impasse Procedures," Industrial and Labor Relations Review, Vol. 35, No. 1 (October 1981), pp. 3 - 20.
}

the overall patterns and variations in industrial relations and economic outcomes across these plants. We then review the intercorrelations between the industrial relations performance measures and test the correlations among economic performance, industrial relations, and environmental factors. Finally, we assess the effects of the QWL efforts.

\section{Results}

At the outset, we noted the importance of examining the diversity of outcomes that are produced by collective bargaining in different bargaining relationships. The statistics in Table 1 illustrate this point. Despite the common technology, union, and employer from which these data are drawn, there is a wide variation across plants in grievance rates, discipline rates, absenteeism, and the other industrial relations and economic performance measures. Note that in 1979 , for example, grievances per 100 workers varied from a low of 24 in one plant to a high of 450 in another plant. Absenteeism varied between 4.7 and 10.3 percent. The number of contract demands introduced in the local negotiations for the 1979 agreement varied from a low of 102 to a high of 754. The economic significance of the variation in the indices of economic performance is not as easily interpreted, since these indices are a product of GM's particular accounting and quality-control systems. Nonetheless, these figures do show considerable variation around their means and again illustrate the need to investigate conditions within the plants to determine the causes of these variations and the effects of labor-management relations.

Time plots of the data reveal that an important source of variation appears to be the business cycle and thus the volume of work in the plants. ${ }^{13}$ There were sharp increases in grievance activity and absenteeism and declines in direct-labor efficiency during the growth years of $1970-73$, followed by opposite movements in these variables as the oil embargo and the

\footnotetext{
${ }^{19}$ These plots are available from the authors upon request.
} 
Table 1. Measures of Industrial Relations and

Economic Performance in 18 Plants, 1979.

\begin{tabular}{lrrrr}
\hline & Mean & Minimum & Maximum & Standard Deviation \\
\hline Grievances & 124.3 & 24.5 & 450.2 & 133.1 \\
Absenteeism & 7.4 & 4.7 & 10.3 & 1.7 \\
Discipline & 44.5 & 20.0 & 86.8 & 17.5 \\
Contract Demands & 364.6 & 4.0 & 1163.0 & 196.4 \\
Negotiation Time & 76.8 & -110.0 & 532.0 & 143.4 \\
Climate & 2.9 & 2.2 & 3.8 & .5 \\
Product Quality & 127.6 & 122.0 & 137.0 & 3.7 \\
Direct-Labor Efficiency & 87.4 & 57.1 & 103.7 & 13.2 \\
\hline
\end{tabular}

Legend.

Grievances: the number of grievances filed per 100 workers.

Absenteeism: the absentee rate as a percentage of straight-time hours, excluding contractual days off.

Discipline: the number of oral warnings, disciplinary leaves, and discharges assessed per 100 workers.

Contract Demands: the number of contract demands submitted by the local union in tri-annual local contract negotiations.

Negotiation Time: the number of days taken to reach settlement in local contract negotiations before (negative) or after (positive) settlement of the master agreement between GM and the UAW international.

Climate: an average score (based on a one to five response format) on five survey questions measuring the state of labor-management relations in the plant. The survey was administered to all managerial and supervisory employees in the plant. The higher the average score, the more cooperative the relations.

Product Quality: an index derived from a count of the number of faults and demerits that appear in inspections of the product adjusted for differences in product attributes.

Direct-Labor Efficiency: an index comparing the actual hours of direct labor input to standardized hours adjusted for differences in product attributes.

consequent decline in auto sales took effect between 1973 and 1975. As the industry recovered during the years 1976-79, grievance activity and absenteeism again rose and direct-labor efficiency fell substantially. The implication of these variations for our subsequent analyses is that we do need to control for both the effects of variations in the volume of production activity in the plants and plant-specific effects that are not captured by the general environmental measures available to us.

\section{Industrial Relations Performance Measures}

The correlations among the measures of industrial relations performance are presented in Table 2 . The relationships are all in the expected direction, and twelve out of fifteen are statistically significant beyond the one percent level. These data thus provide strong support for the proposition that these industrial relations performance measures are systematically related in a reinforcing cycle. In particular, the more cooperative the attitudinal climate between the local union and management, the lower the grievance rate $(\mathrm{r}=-.77)$, discipline rate $(\mathrm{r}=-.20)$, and absenteeism ( $\mathrm{r}=-.49)$; the fewer the demands introduced by the union in contract negotiations $(r=-.49)$; and the less the negotiating time required to reach an agreement $(\mathrm{r}=-.52)$.

Similarly, grievance, discipline, and absenteeism rates are all positively and significantly correlated with one another and positively correlated with the number of contract demands and the length of negotiation time required to reach a local agreement. Others have argued that these interrelationships should exist, ${ }^{14}$ but to our knowledge, this is the first empirical

${ }^{14}$ Kochan, Collective Bargaining and Industrial Relations, pp. 390-95; David Peach and E. Robert Livernash, Grievance Initiation and Resolution: $A$ Study in Basic Steel (Boston: Graduate School of 
Table 2. Interrelationships Among Industrial Relations Performance Variables as Measured by Simple Correlation Coefficients. ${ }^{\dagger}$

\begin{tabular}{|c|c|c|c|c|c|c|}
\hline & Climate & Grievances & Discipline & Absenteeism & $\begin{array}{l}\text { Contract } \\
\text { Demands }\end{array}$ & $\begin{array}{c}\text { Negotiation } \\
\text { Time }\end{array}$ \\
\hline Climate & 1.00 & & & & & \\
\hline Grievances & $-.77 * *$ & 1.00 & & & & \\
\hline Discipline & -.20 & $.44^{* *}$ & 1.00 & & & \\
\hline Absenteeism & $-.49^{* *}$ & $.26^{* *}$ & $.43^{* *}$ & 1.00 & & \\
\hline Contract Demands & $-.49^{* *}$ & $.31 * *$ & $.31 * *$ & $.31 * *$ & 1.00 & \\
\hline Negotiation Time & $-.52^{* *}$ & $.57 * *$ & $.30 * *$ & .16 & .17 & 1.00 \\
\hline
\end{tabular}

\footnotetext{
${ }^{\dagger}$ The number of observations ranges between 171 and 176 for correlations involving measures of absenteeism, grievances, and discipline. The number of observations ranges between 65 and 68 for correlations involving climate, contract demands, and negotiation time. All variables are as defined in Table 1.

* Statistically significant at .05 level in a two-tailed test.

** Statistically significant at .01 level in a two-tailed test.
}

confirmation provided for this general proposition.

\section{Industrial Relations Performance, Environmental Factors, and Economic Performance}

Correlations between measures of economic performance (indices of product quality and direct-labor efficiency) and the industrial relations performance and environmental measures are presented in Table 3. Eleven of the twelve correlations between the economic and industrial relations performance measures are in the expected direction. Ten of the twelve are statistically significant at the 5 percent level, and nine out of the twelve are statistically significant at the one percent level. Higher grievance and discipline rates are related to lower quality and lower labor efficiency. Higher absenteeism is related to lower efficiency. Surprisingly, higher absenteeism is also related to higher quality, although the correlation with quality does not reach conventional levels of statistical significance. ${ }^{15}$ Fewer difficulties in nego-

Business, Harvard University, 1974); Andrew J.W. Thomson and Victor V. Murray, Grievance Procedures (London: Saxon House, 1976); and Thomas R. Knight, Factors Affecting the Arbitration Submission Rate: A Comparative Case Study, M.S. thesis (Ithaca, N.Y.: New York State School of Industrial and Labor Relations, Cornell University, 1978).

${ }^{15}$ The data show a rise in both quality and absenteeism in the late $1970 \mathrm{~s}$, which may confound tiating new contracts (fewer demands and fewer days required) are related to higher quality and lower costs. There is also evidence that economic performance is related to the volume of economic activity in the plant, as measured by total work hours and the overtime ratio.

These correlations support our theoretical argument that industrial relations performance affects economic performance. The existence of these effects also provides support for the parties' decision to embark on a strategy to improve industrial relations performance in these plants. Evidence of the association between attitudinal climate and economic performance provides particularly strong justification for the QWL programs, since QWL advocates argue that these attitudes are one of the key initial targets of QWL efforts. We shall now turn to the analysis of the impact of the QWL efforts in these plants.

\section{Analysis of the Impact of QWL}

Our underlying model hypothesizes that QWL efforts affect economic performance, industrial relations performance, and workers' perceptions of the quality of their jobs. Before proceeding to a review of our findings, it is important to note that our

evaluations of the connection between the two variables. Correlations of data from plants within a given year consistently reveal an association between high product quality and low absentee rates. 
Table 3. Correlations of Economic Performance with Industrial Relations Performance and Environmental Characteristics. ${ }^{\dagger}$

\begin{tabular}{lcc}
\hline & Product Quality & Direct-Labor Efficiency \\
\hline Grievances & $-.27^{* *}$ & $-.49^{* *}$ \\
Discipline & $-.20^{*}$ & $-.35^{* *}$ \\
Absenteeism & .13 & $-.38^{* *}$ \\
Climate & $.44^{* *}$ & $.44^{* *}$ \\
Contract Demands & -.20 & $-.32^{* *}$ \\
Negotiation Time & $-.39^{* *}$ & $-.40^{* *}$ \\
Total Hours & -.05 & $-.24^{* *}$ \\
Overtime Ratio & .05 & $-.29^{* *}$ \\
\hline
\end{tabular}

\footnotetext{
${ }^{\dagger}$ The number of observations ranges between 65 and 68 for correlations involving climate, contract demands, and negotiation time. For all other variables, the number of observations ranges between 126 and 176 . Total hours is the total annual work hours of all production workers, and overtime ratio is the annual number of overtime hours divided by the number of straight-time hours worked by all production workers. All other variables are as defined in Table 1.

*Statistically significant at .05 level in a two-tailed test.

**Statistically significant at .01 level in a two-tailed test.
}

data unfortunately provide no measure of job quality; thus, the possibly important impact of QWL efforts on job quality cannot be addressed in this analysis.

Changes in high and low QWL plants. To assess the impact of the QWL efforts, we first compare, in Table 4, changes in the industrial relations and economic performance of the five plants with the highest QWL program ratings (or intensity) in 1977 with changes in the performance of the five plants with the lowest QWL program ratings in 1977. We look at changes before and after 1977 because discussion with QWL staff in these plants led us to believe that although the QWL effort was formally announced in 1973, it was not until 1977 that QWL programs were actually in progress in most of the plants. Also recall that measurement of QWL programs did not begin until 1977.

From 1974 to 1976, except for directlabor efficiency, industrial relations and economic performance of the plants that later developed high QWL program ratings declined relative to the performance measures of the five plants that later developed low QWL program ratings. For instance, in the plants with high QWL program ratings, grievance and absentee rates rose 17.6 and 47.5 percent on average from 1974 to 1976 , whereas in the plants with low QWL program ratings, grievance and absentee rates rose 4.3 and 23.4 percent.

In contrast, from 1977 to 1979 , industrial relations and economic performance, except for grievance rates, improved in the five plants with high QWL program ratings relative to performance in the five plants with low QWL program ratings. The plants with the highest QWL program ratings on average had a 1.5 percent improvement in their quality index, whereas the plants with the lowest QWL ratings had a .2 percent decrease in their quality index. With respect to absentee rates over the $1977-79$ period, the plants with the most QWL activity had a 1.8 percent increase, whereas the five with the least activity had a 20.6 percent increase.

Within the top and bottom groups, however, there was wide variation among plants in changes in industrial relations and economic performance. Thus, none of the differences in the changes in performance from 1977 to 1979 between the top and bottom five plants are statistically significant at even the .10 level.

Regression analysis. Another way to measure the impact of QWL programs with these data is to enter the QWL program ratings as an independent variable in regression analyses in which 
Table 4. Comparison of the Percent Change in Economic and

Industrial Relations Performance in the Five Plants with the Highest and the Five with the Lowest 1977 QWL Program Rating.

\begin{tabular}{lcccccc}
\hline & \multicolumn{2}{c}{ Percent Change, 1974-76 } & & \multicolumn{2}{c}{ Percent Change, 1977-79 } \\
\cline { 2 - 3 } \cline { 5 - 6 } Variable $^{\dagger}$ & $\begin{array}{c}\text { Five Plants with } \\
\text { Highest 1977 } \\
\text { QWL Rating }\end{array}$ & $\begin{array}{c}\text { Five Plants with } \\
\text { Lowest 1977 } \\
\text { QWL Rating }\end{array}$ & & $\begin{array}{c}\text { Five Plants with } \\
\text { Highest 1977 } \\
\text { QWL Rating }\end{array}$ & $\begin{array}{c}\text { Five Plants with } \\
\text { Lowest 1977 } \\
\text { QWL Rating }\end{array}$ \\
\hline Product Quality & 4.2 & 6.1 & & 1.5 & -0.2 \\
Direct-Labor Efficiency & 5.5 & 4.7 & & -2.4 & -4.8 \\
Grievances & 17.6 & 4.3 & & 5.2 & 4.8 \\
Absenteeism & 47.5 & 23.4 & & 1.8 & 20.6 \\
Discipline & 42.1 & 18.8 & & 6.0 & 11.5 \\
\hline
\end{tabular}

${ }^{\dagger}$ All variables are as defined in Table 1.

economic performance indices are the dependent variables and environmental variables are included as control variables. In some of these regressions, we also enter as further controls grievance and absentee rates and plant dummy variables. On the other hand, concerned that these additional control variables might "overcontrol" and strip the QWL program variable of its true effects, we do not include the industrial relations performance measures and dummy variables as control variables in some of the regressions.

Because of our inability to measure the intensity of QWL programs prior to 1977 , we enter a score of zero for the QWL program rating ( $Q W L R A T E$ ) in each plant for the years prior to 1977. Undoubtedly, this introduces some measurement error, but this procedure has the advantage of allowing us to use other plant characteristics (environmental and industrial relations) prior to 1977 as controls in the estimation. Before reporting the results of this analysis, we should also note that this specification focuses on the impact that QWL programs in place in any given year exert on economic performance in that year. This specification may, however, ignore some of the dynamic effects of QWL programs that appear over time.

Tables 5 and 6 report the results of these regressions for pooled time-series and crosssection plant-level data from the years 1970-79. In Table 5, the sign of the coefficients on QWL rating implies that more-intensive QWL programs are associated with better product quality. In all four regressions, the coefficient on QWL rating is statistically significant at the one percent level. Also, when the grievance and absentee rates are not included as control variables, the coefficient on QWL rating is higher and has a higher $t$-statistic, suggesting that some of the positive effect of the QWL programs on quality is transmitted through the influence of QWL efforts on grievance and absentee rates. We interpret these results as initial support for our hypothesis that QWL efforts can improve economic performance through their effects on industrial relations performance.

The sign of the coefficients on QWL rating in Table 6 , where direct-labor efficiency is the dependent variable, implies that more-intensive QWL programs are associated with lower efficiency and higher labor costs; however, none of these coefficients is statistically significant at even the 10 percent level. This finding is inconsistent with the evidence provided in Table 4, which shows that the five plants with high QWL ratings in 1977 had relative improvements in their direct-labor efficiency from 1977 to 1979. Before discussing a potential source of this inconsistency, we will review a few other results from the regressions.

Whenever the grievance rate is included as a control variable in the regressions reported in Tables 5 and 6 , higher grievance rates are associated with lower 
Table 5. Regression Analysis of the Effect of Environmental, Industrial Relations, and QWL Rating Measures on Product Quality.

(standard errors in parentheses)

\begin{tabular}{|c|c|c|c|c|}
\hline \multirow[b]{2}{*}{ Explanatory Variables ${ }^{a}$} & \multirow[b]{2}{*}{$(1)^{b}$} & \multicolumn{2}{|c|}{ Estimated Coefficients } & \multirow[b]{2}{*}{$(4)^{c}$} \\
\hline & & $(2)^{b}$ & $(3)^{c}$ & \\
\hline Intercept & $\begin{array}{c}111.207^{* *} \\
(3.149)\end{array}$ & $\begin{array}{c}116.021^{* *} \\
(2.372)\end{array}$ & $\begin{array}{c}123.340^{* *} \\
(1.548)\end{array}$ & $\begin{array}{c}124.049^{* *} \\
(1.226)\end{array}$ \\
\hline Overtime & $\begin{array}{c}.082 \\
(.078)\end{array}$ & $\begin{array}{l}.101 \\
(.084)\end{array}$ & $\begin{array}{c}.049 \\
(.082)\end{array}$ & $\begin{array}{c}.048 \\
(.082)\end{array}$ \\
\hline Total Hours & $\begin{array}{c}-.132 \\
(.334)\end{array}$ & $\begin{array}{c}-.122 \\
(.318)\end{array}$ & $\begin{array}{c}-.184 \\
(.178)\end{array}$ & $\begin{array}{c}-.272 \\
(.181)\end{array}$ \\
\hline Grievances & $\begin{array}{c}-.027^{* *} \\
(.009)\end{array}$ & & $\begin{array}{c}-.019 * * \\
(.005)\end{array}$ & \\
\hline Absenteeism & $\begin{array}{l}1.167 * * \\
(.330)\end{array}$ & & $\begin{array}{l}.320 \\
(.260)\end{array}$ & \\
\hline QWL Rating & $\begin{array}{l}.183^{* *} \\
(.056)\end{array}$ & $\begin{array}{l}.281^{* *} \\
(.054)\end{array}$ & $\begin{array}{l}.240^{* * *} \\
(.059)\end{array}$ & $\begin{array}{l}.267 * * \\
(.060)\end{array}$ \\
\hline $\begin{array}{l}\mathbf{R}^{2} \\
\mathbf{F}\end{array}$ & $\begin{array}{l}.606 \\
7.20\end{array}$ & $\begin{array}{l}.529 \\
5.89\end{array}$ & $\begin{array}{l}.231 \\
7.23\end{array}$ & $\begin{array}{l}.153 \\
7.35\end{array}$ \\
\hline $\mathbf{N}$ & 126 & 126 & 126 & 126 \\
\hline
\end{tabular}

${ }_{b}^{a}$ All variables are as defined in Tables 1 and 3.

${ }^{b}$ Plant dummy variables included as a set statistically significant at the .01 level in an $F$ test.

${ }^{c}$ Plant dummy variables not included.

** Statistically significant at the .01 level in a two-tailed test.

Table 6. Regression Analysis of the Effect of Environmental, Industrial Relations, and QWL Program Rating Measures on Direct-Labor Efficiency. ${ }^{a}$ (standard errors in parentheses)

\begin{tabular}{|c|c|c|c|c|}
\hline \multirow[b]{2}{*}{ Explanatory Variables ${ }^{a}$} & \multirow[b]{2}{*}{$(1)^{b}$} & \multicolumn{2}{|c|}{ Estimated Coefficients } & \multirow[b]{2}{*}{$(4)^{c}$} \\
\hline & & $(2)^{b}$ & $(3)^{c}$ & \\
\hline Intercept & $\begin{array}{c}126.305^{* *} \\
(5.387)\end{array}$ & $\begin{array}{c}127.272^{* *} \\
(3.829)\end{array}$ & $\begin{array}{l}96.949 * * \\
(2.316)\end{array}$ & $\begin{array}{c}103.815 * * \\
(2.078)\end{array}$ \\
\hline Overtime & $\begin{array}{c}-.053 \\
(.133)\end{array}$ & $\begin{array}{c}-.006 \\
(.136)\end{array}$ & $\begin{array}{c}-.114 \\
(.130)\end{array}$ & $\begin{array}{c}-.349^{*} \\
(.143)\end{array}$ \\
\hline Total Hours & $\begin{array}{c}-.099 \\
(.533)\end{array}$ & $\begin{array}{c}-.619 \\
(.496)\end{array}$ & $\begin{array}{c}-.001 \\
(.278)\end{array}$ & $\begin{array}{c}-.347 \\
(.312)\end{array}$ \\
\hline Grievances & $\begin{array}{c}-.047^{* *} \\
(.014)\end{array}$ & & $\begin{array}{c}-.050^{* *} \\
(.008)\end{array}$ & \\
\hline Absenteeism & $\begin{array}{l}.567 \\
(.550)\end{array}$ & & $\begin{array}{c}-1.336^{* *} \\
(.410)\end{array}$ & \\
\hline QWL Rating & $\begin{array}{c}-.153 \\
(.105)\end{array}$ & $\begin{array}{c}-.050 \\
(.095)\end{array}$ & $\begin{array}{c}-.039 \\
(.103)\end{array}$ & $\begin{array}{c}-.021 \\
(.111)\end{array}$ \\
\hline $\begin{array}{l}\mathbf{R}^{2} \\
\mathbf{F}\end{array}$ & $\begin{array}{l}.549 \\
8.19\end{array}$ & $\begin{array}{l}.508 \\
7.78\end{array}$ & $\begin{array}{l}.320 \\
15.55\end{array}$ & $\begin{array}{l}.093 \\
5.73\end{array}$ \\
\hline $\mathbf{N}$ & 171 & 171 & 171 & 171 \\
\hline
\end{tabular}

${ }_{b}^{a}$ All variables are as defined in Tables 1 and 3.

${ }^{b}$ Plant dummy variables included as a set statistically significant at the .01 level in an $F$ test.

${ }^{c}$ Plant dummy variables not included.

* Statistically significant at the .05 level in a two-tailed test.

** Statistically significant at the .01 level in a two-tailed test. 
product quality and lower direct-labor efficiency, and these associations are both statistically significant at the one percent level. This finding lends further support to our hypothesis that the level of industrial relations conflict affects economic performance at the plant level.

The association between absentee rates and quality and direct-labor efficiency in the regression analysis is not consistent. Higher absenteeism is associated with better product quality, and in one of the regressions, this association is statistically significant at the one percent level. Nonetheless, this may merely reflect the rise in both quality and absenteeism in the late $1970 \mathrm{~s}$ mentioned earlier. In one of the regressions, higher direct-labor efficiency is associated with lower absentee rates at a statistically significant level of one percent, although in another regression, this association is reversed and is not statistically significant.

Whenever they are included in the regressions, the plant dummy variables are statistically significant as a set at the one percent level. ${ }^{16}$ This result indicates that there are a number of unmeasured plant characteristics that also affect economic performance.

Issues of selection bias. One difficulty in assessing the validity of this estimation procedure is whether the specification fully adjusts for potential selection bias in this sample of differentially distributed QWL activities. For instance, the positive association between QWL program rating and lower direct-labor efficiency (Table 6) could be the result of the fact that moreextensive QWL programs were carried out in plants that for some unmeasured reason already had lower efficiency.

To analyze the issue of selection bias, we measure the correlation between QWL ratings in 1977 and measures of economic and industrial relations performance in 1976. We also measure the correlation between QWL ratings in 1979 and eco-

\footnotetext{
${ }^{16} \mathrm{An} F$ test is performed on the set of dummy variables because $F$ tests on individual plant dummy variables will vary as a function of whichever plant is used as the control group in the test.
}

nomic and industrial relations performance in 1978. These correlations, reported in Table 7, show that in 1977, moreextensive QWL programs tended to appear in plants that in 1976 had shown good economic and industrial relations performance. For instance, the 1977 QWL rating is negatively correlated with 1976 absentee and grievance rates and positively associated with labor efficiency. By 1979, this pattern had largely reversed, as illustrated by the fact that the 1979 QWL rating is positively correlated with 1978 absentee rates and negatively correlated with labor efficiency. Note, however, that many of these correlations are weak; only one correlation is statistically significant at the 5 percent level, and some of the signs of the correlations are inconsistent with the overall pattern.

Overall, the correlations reported in Table 7 provide some evidence that in the early stages of their introduction, QWL programs were more extensive in GM's better-performing plants. After observing the success of the programs in those plants, GM apparently decided to develop QWL programs more extensively in plants that had had histories of poor performance. A number of implications follow from this pattern. For one thing, the inconsistent impact of QWL as measured in the regression model may be the result of our inability to account fully for selection bias caused by the particular distribution of QWL activity. ${ }^{17}$ Second, the way in which QWL spread throughout these particular plants offers some insight into how a workplace innovation like QWL is diffused in an organization. Furthermore, the existence of a diffusion pattern suggests that future evaluations of QWL programs in place at GM or elsewhere must take account of selection bias or else misleading findings may result.

\footnotetext{
${ }^{17} \mathrm{~A}$ possible methodology for future research is estimation of a two-stage model that includes an equation having the QWL program measure as the dependent variable. At this time and with these data, we are not confident of our ability to predict QWL development with this kind of linear model.
} 
Table 7. Correlation of QWL Rating and Economic and Industrial Relations Performance. ${ }^{\dagger}$

\begin{tabular}{lccccc}
\hline QWL Rating & $\begin{array}{c}\text { Product } \\
\text { Quality }\end{array}$ & $\begin{array}{c}\text { Direct-Labor } \\
\text { Efficiency }\end{array}$ & Grievances & Absenteeism & Discipline \\
\hline Rating in 1977 & -.120 & \multicolumn{7}{c}{1976} \\
& $(.636)$ & $(.042)$ & -.463 & -.363 & .086 \\
& \multicolumn{7}{c}{1978} & & $(.053)$ & $(.139)$ & $(.733)$ \\
Rating in 1979 & -.024 & -.167 & -.195 & .169 & -.185 \\
& $(.924)$ & $(.510)$ & $(.439)$ & $(.502)$ &.$(.463)$ \\
\hline
\end{tabular}

\footnotetext{
${ }^{\dagger}$ The numbers in parentheses are statistical-significance levels of each correlation. There are 18 observations in each year. All variables are as defined in Tables 1 and 3.
}

\section{Discussion}

The results of this study provide initial support for the proposition that measures of industrial relations performance, such as grievance and discipline rates, unionmanagement climate, absenteeism, and difficulty in contract negotiations, are systematically interrelated and also strongly related to measures of economic performance, such as direct-labor efficiency and product quality.

Less conclusive are the results of our tests of the proposition that QWL efforts have produced improvements in industrial relations and economic performance across the eighteen plants studied. There is some evidence in Table 4 of greater marginal improvements in economic and industrial relations performance in plants that developed a high level of QWL activity than in those with a low level of QWL activity. In Table 5, regression analysis shows an association between more-extensive plantlevel QWL activity and better product quality. There is also evidence that some of the impact of QWL activity on product quality is transmitted through its effect on industrial relations performance (that is, on grievance and absentee rates). In Table 6 , however, regression analysis does not reveal a positive association between moreextensive QWL activity and higher directlabor efficiency.

Our evaluation of these QWL efforts is frustrated by the complicated diffusion pattern of QWL activities shown in Table 7. The evaluation is also limited by the short time period in which the effects of the programs could be observed and by the weaknesses in our measure of the intensity of QWL efforts. We will return to a discussion of the implications of these limitations for future research after discussing the theoretical meaning of the strong relationships observed between industrial relations and economic performance in these plants.

Toward a theoretical rationale. Practitioners who promote QWL principles and who would like to reduce the adversarial elements of the U.S. industrial relations system may find it rather "academic" to ask whether a clear theoretical rationale exists to support these strategies. Yet, if this experimental atmosphere is to be translated into lasting improvements in the conduct of industrial relations at the plant level, we must have a better understanding of why and how industrial relations performance affects organizational effectiveness and how QWL or similar innovations might improve these outcomes. The empirical results reported in this exploratory study further underscore the importance of finding a better theoretical explanation of current initiatives.

Both results and the current increase in QWL activities in enterprises suggest that an avenue by which productivity in unionized settings can be improved is through more effective management of conflict and greater collaboration at the workplace. What explains these results and this growth in activity? Clearly, more is involved than the simple and empirically unsubstantiated proposition of the human relations move- 
ment that greater productivity will result from increasing individual workers' satisfaction and group cooperation. ${ }^{18}$ We believe that a more complete understanding lies in a closer examination of the consequences of various means of managing conflict at the workplace.

Fox has argued that the central problem of industrial relations is overcoming the high-conflict and low-trust dynamic that can be set in motion within a bargaining relationship. ${ }^{19}$ Indeed, we see the reinforcing cycle of correlations shown in Table 2 as illustrative of Fox's argument. A high level of formal grievance and discipline cases, a poor attitudinal climate between the union and management, high levels of absenteeism, and difficult contract negotiations indicate ineffective conflict management at the plant level and symbolize the carryover of the high-conflict and low-trust dynamic from one part of the employment relationship to another. This cycle ultimately affects economic performance. The diversity of industrial relations and economic performance throughout GM is testimony to the fact that there is wide variation in the extent to which labor relations practice in these plants is caught up in this cycle.

QWL efforts, then, can be seen as one strategy for attempting to break out of the cycle of high conflict and low trust. Such change might lead to improved economic performance in at least three ways. First, there may be a displacement effect, as fewer resources and emotional energies have to be allocated either to processing or resolving conflicts through the formal adversarial procedures or to creating stronger and more complex rules and control procedures to manage the work force. The function of the personnel and industrial relations departments can thus shift in emphasis from processing grievances and administering the adversarial aspects of the employment relation-

\footnotetext{
${ }^{18}$ See Donald P. Schwab and Larry L. Cummings, "Theories of Satisfaction and Performance: A Review," Industrial Relations, Vol. 9, No. 4 (October 1970), pp. 408 - 30.

${ }^{19}$ Alan Fox, Beyond Contract: Work, Power and Trust Relations (London: Faber, 1974), pp. 248-313.
}

ship to an emphasis on training supervisors in effective communication and problem solving.

A second result of moving away from the adversarial cycle may be the enhanced motivation of individual workers. To the extent that workers are interested in more participation in job-related decision making, they may respond to these strategies by sharing their ideas on how to improve work performance, increasing their commitment to the job and the firm, and performing more effectively. We might call this the communication-motivationcommitment cycle. ${ }^{20}$

Finally, these efforts may provide some direct payoffs to the firm in the form of greater flexibility in human resource management. There may be, that is, fewer rules regarding who does what tasks, more training in how to do a wider variety of tasks, and fewer constraints on how the work is organized.

Modifications in the high-conflict and low-trust cycle may offer some of these positive returns to employers and employees, but we do not expect that QWL efforts will produce an end to the adversarial relationship between labor and management, as many of the more ardent supporters of the QWL programs suggest. Indeed, those who expect either an end to conflict at the workplace or a solution to the nation's productivity problems as the result of QWL efforts fall into the same trap as many members of the human relations school did years ago, when they ignored the larger economic and structural contexts of the employment relationship. Clearly, the parties in the auto industry, and in other industries as well, continue to face major differences in economic interests differences that require negotiation, com-

\footnotetext{
${ }^{20}$ For two different theoretical models that are consistent with this argument, see J. Richard Hackman and Greg R. Oldham, "Motivation Through the Design of Work: Test of a Theory," Organizational Behavior and Human Performance, Vol. 16, No. 2 (August 1976), pp. 250 - 74; and Richard E. Walton, "Establish ing and Maintaining High Commitment Work Systems," in John R. Kimberly and Robert A. Miles, eds. The Organizational Life Cycle: Issues in the Creation, Transformation and Decline of Organizations (San Francisco: Jossey Bass, 1980), pp. 208-90.
} 
promise, and periodic adjustment. The tension between shop-floor cooperation and adversarial bargaining will be greatest when contract negotiators confront difficult problems. Thus, the key to the success of these QWL efforts will lie in whether they are able to maintain effective collaboration at the workplace level over an extended period of time and, especially, during periods when difficult problems are being resolved within the bargaining relationship.

Implications for research. Future researchers investigating the role and impact of QWL or other worker-participation programs in unionized settings can draw the following inferences from this study. One task of future research should be to develop better measures of QWL activities. It is also clear that we need to trace the effects of these programs over a longer period of time to test the staying power of cooperative efforts in the midst of mixedmotive bargaining. ${ }^{21}$ The role that union participation plays in QWL programs also remains unexamined. Although local union support for the QWL programs in our sample varied substantially, no direct measure of union support was available.

\footnotetext{
${ }^{21}$ For a theoretical discussion of the employment relationship as a mixed-motive situation, see Walton and McKersie, A Behavioral Theory, pp. 161-83.
}

Future researchers should test the hypothesis that QWL efforts have different degrees of success or longevity depending on whether unions are joint partners in the program or management initiates all activities and the local union adapts a neutral or an antagonistic role. We also need further theoretical elaboration of the channels through which industrial relations performance and QWL efforts affect economic performance.

Finally, most previous research (and to some extent, the research reported here as well) fails to relate QWL and other cooperative efforts at the workplace to the broader strategies and events that affect relations between a union and an employer. ${ }^{22}$ Only by examining how these innovations fit into the larger industrial relations system in which they are embedded will we be able to determine whether they are simply another in a long list of short-lived fads at the workplace or in fact represent the beginnings of a new industrial relations system.

\footnotetext{
${ }^{22}$ For a discussion of some of these broader issues, see Harry C. Katz, "Assessing the New Auto Labor Agreements," Sloan Management Review, Vol. 23, No. 4 (Summer 1982), pp. 57 - 63; and Harry C. Katz, "The U.S. Automobile Collective Bargaining System in Transition," British Journal of Industrial Relations (forthcoming).
} 


\section{Appendix \\ The QWL Content Analysis}

The QWL content analysis was performed in the following manner. Cards that listed the representative QWL activities below were provided to five industrial relations professors and graduate students with expertise in QWL programs, who were asked to rank these activities in three categories according to the significance they attached to the activity. The three categories then were assigned the following weights: minor significance, one point; intermediate significance, two points; and major significance, three points. An average weight was derived for each activity based on the rankings provided by the five experts. Another expert then recorded the occurrence of these activities in each plant, by using plant managers' annual reports that describe the QWL activities within each plant. Each activity was assigned its weight, and a total QWL score was computed for each plant for each year (1977 $80)$. In a test of the reliability of this scoring procedure, a second expert also reviewed the annual reports and assigned the appropriate weight. The correlation between the scores obtained by the two experts was .85 .

\section{List of Representative QWL Activities}

1. Open house and plant tours for employee families or community residents, or both.

2. Community relations projects such as blood drives or United Way campaigns.

3. Physical-plant improvements, such as painting the walls or housekeeping improvements.

4. Off-site training or problem-discussion meetings with salaried staff.

5. Off-site training or problem-discussion meetings with hourly workers.

6. Off-site meetings between plant management and union representatives.

7. Alcohol- or drug-abuse programs.

8. Experimental projects that involve specific work groups in the plant.

9. Promotional programs that advertise the plant, such as plant T-shirts, jackets, or pens.

10. Consultation meetings with hourly workers or union representatives over future QWL initiatives.

11. Formation (or continuation) of a union- management QWL or other committee.

12. Use of an outside consultant (or a GM or UAW QWL specialist).

13. Special programs emphasizing product quality, offering such rewards as prizes, cash, or recognition.

14. Motivational films or other media presentations to the work force.

15. Feedback of QWL survey to workers or union representatives, or both.

16. Joint GM-UAW orientation programs for new hires.

17. Management's sharing information on plans for plant expansion, renovation, or other changes with workers or union representatives, or both.

18. Upward communications programs, such as question boxes, suggestion boxes, or plant newsletters.

19. Special dinners or luncheons for, for example, retiring employees, Christmas, or other occasions.

20. Enhancing the role of the first-line supervisors, such as through special seminars. 
Copyright of Industrial \& Labor Relations Review is the property of Cornell University. The copyright in an individual article may be maintained by the author in certain cases. Content may not be copied or emailed to multiple sites or posted to a listserv without the copyright holder's express written permission. However, users may print, download, or email articles for individual use. 